\title{
WSPOMNIENIE O PROFESORZE JERZYM TOPOLSKIM
}

\section{Lech TRZECIAKOWSKI}

Pamięcią sięgam czasów odległych. Był rok 1959 kiedy poznałem profesora Topolskiego. Wczesną wiosną rozeszła się wieść, że Topolski wraca z Warszawy do Poznania. Poprzedzała go sława młodego wybitnego uczonego. Miał wtedy 31 lat. Któregoś dnia dyżurowałem w bibliotece Instytutu, kiedy otworzyły się drzwi, w których ukazał się młody gentelman. Podszedł do mnie i przedstawił się „Topolski jestem”. Nim zdołałem odpowiedzieć zniknął w głębi biblioteki. Wkrótce zaprzyjaźniliśmy się.

$\mathrm{Z}$ reguły humaniści na szczyty uznania wspinają się latami, a szczególnie historycy. Niwa, którą uprawiają wymaga wieloletnich, żmudnych badań bibliotecznych i archiwalnych, które w postaci dzieł naukowych owocują po latach. Trzeba mieć wyjątkowy talent, aby już w tak młodym wieku zajaśnieć pełnym blaskiem, talent, wsparty blyskotliwością, niebywałą pracowitością, fenomenalną erudycją, umiejętnością koncentracji na ważnych problemach, na stworzeniu warsztatu naukowego. Wszystkie te przymioty posiadał profesor Jerzy Topolski.

Urodził się w Poznaniu 20 września 1928 roku. Rodzice byli nauczycielami. Lata szkolne i czas tuż powojenny spędził w Gnieźnie, mieście, któremu w przyszłości poświęcił wspaniałą monografię. Profesor Topolski swoją świetną karierę naukową zawdzięcza wspaniałym mistrzom, prof. Janowi Rutkowskiemu i Pawłowi Sulmickiemu, pod okiem których rozpoczął rozwijać bogatą i wielokierunkową twórczość. Wcześnie, bo już w 1961 roku uzyskał tytuł naukowy profesora nadzwyczajnego, w 1971 roku został członkiem nadzwyczajnym Polskiej Akademii Nauk, a w 1977 członkiem rzeczywistym. Doceniono w ten sposób bogaty dorobek profesora obejmujący kilka ważnych pól badawczych. Pierwsze to studia nad dziejami gospodarczymi w XVI i XVII wieku. Dotyczyly one tak 
przeszłości Polski, jak i dziejów powszechnych. W tym zakresie J. Topolski starał się odpowiedzieć na jedno z fundamentalnych pytań dotyczących przyczyn podziału Europy, na jej zachodni obszar rozwijających się stosunków kapitalistycznych, opartych o akumulację typu kapitalistycznego i związaną z tym słabnącą pozycją szlachty na rzecz mieszczaństwa oraz Europę na wschód od Łaby, gdzie na skutek dominacji szlachty nastąpiła refeudalizacja przez rozwój gospodarki folwarczno-pańszczyźnianej. Akumulacja typu feudalnego służyła szlachcie, a w minimalnym stopniu z jej dobrodziejstw korzystało mieszczaństwo i chłopstwo. Jak wiadomo, w następnych stuleciach trudno było przezwyciężyć spuściznę tego podziału, a i dziś dostrzegalny jest długi cień tamtej epoki. Rozważania te znalazły odbicie w licznych publikacjach w języku polskim, jak i językach kongresowych, przede wszystkim w Narodzinach kapitalizmu $w$ Europie XIV-XVII wieku, która zdobyła powszechne uznanie i służyła jako model interpretacyjny dla innych prowadzonych w tym zakresie badań. Wyrazem tego było powołanie Profesora do Międzynarodowego Stowarzyszenia Historii Gospodarczej (Association Internationale d'Histoire Économique).

Prof. Topolski zajmował się także badaniami regionalnymi inicjując niemal wszystkie najważniejsze syntezy dotyczące Wielkopolski i prowadząc pracujące nad nimi zespoły autorów. Za modelowe opracowanie uznać trzeba Dzieje Gniezna (Warszawa 1965). Było to dzieło pionierskie. Do tej pory monografie miast bądź to ujmowały tylko pewne okresy w ich dziejach, bądź były zbiorami studiów. Przedstawiając koncepcję dziejów Gniezna J. Topolski podkreślił, „[... ] że należy opracowywać możliwie systematycznie całokształt dziejów miasta aż do dnia dzisiejszego". Wokół tego projektu skupił prof. Topolski 30 autorów: archeologów, historyków, historyków sztuki. Poza tym gronem 10 osób przygotowywało kwerendy źródłowe. Tu dał znać o sobie lwi pazur Topolskiego jako redaktora naczelnego. Rygorystycznie przestrzegał terminowego oddawania maszynopisów, przeglądał je skrupulatnie i przystosowywał je do ogólnej koncepcji. Anegdotyczną jest perypetia związana z jednym z wybitnych uczonych, autorem jednego z rozdziałów. Uczony ten indagowany przez prof. Topolskiego niezmiennie odpowiadal „już kończę”. Kiedy sytuacja stawała się dramatyczna, na typową stereotypową odpowiedź, Topolski odpowiedział: „to świetnie, jestem u Pana za trzy godziny i odbiorę tekst" i tak długo czekał, aż autor nie wyszedł z maszynopisem. Prace nad Dziejami Gniezna trwały od 1959 do 1965 roku, kiedy to dzieło liczące ponad 1000 stron, ujrzało światło dzienne. Mimo, że minęło wiele lat nadal uchodzi za modelowe ujęcie dziejów miasta. 
Równolegle pochłaniała profesora praca nad dziejami Wielkopolski. Podjął się redakcji pierwszego tomu Dziejów Wielkopolski do roku 1793, obejmującego okres od czasów najdawniejszych po drugi rozbiór Polski. Nowatorstwo tego przedsięwzięcia polegało na zwróceniu uwagi na przemiany w mentalności mieszkańców Wielkopolski, których analiza pozwalała stwierdzić, że Wielkopolska była najbardziej zaawansowanym cywilizacyjnie regionem Rzeczypospolitej.

Kolejnym wielkim przedsięwzięciem, któremu przewodził profesor Topolski były dzieje Poznania. Koncepcję dzieła zaprezentowano w 1970 roku. Integralne ujmowanie procesu historycznego, podkreślanie przemian w mentalności Poznańczyków, zerwanie z polonocentrycznym traktowaniem dziejów miasta, przez oddanie sprawiedliwości Polakom, Niemcom, Żydom i innym narodowościom, które tworzyły to miasto, pozwolił na nowatorskie przedstawienie syntezy dziejów Poznania. Takie ujęcie znalazło bardzo szeroką recepcję, przyniosło szereg odznaczeń naukowych, a poszczególne tomy przygotowane pod refakcją prof. Topolskiego natychmiast stawały się bestsellerami.

Nadszedł czas wielkich syntez. Narodziła się myśl opracowania dziejów Polski przez środowisko poznańskie. Prace trwały kilka lat. W 1975 roku ukazały się Dzieje Polski oparte na założeniu, że dla zrozumienia dziejów Polski podstawowe znaczenie ma integralne traktowanie rozwoju społeczeństwa, narodu i państwa, ujmowanych trójzaborowo, rezygnacja z chronologicznego przedstawiania wydarzeń w poszczególnych dzielnicach na rzecz ich równoczesnego opisu oraz z obiegowo funkcjonujących mitów i poglądów zniekształcających obraz przeszłości.

$\mathrm{Z}$ inicjatywy prof. Topolskiego powstał piąty tom wydawnictwa Dzieje narodu i państwa polskiego. Ukoronowaniem wszelkich syntez było opublikowanie w 1998 roku dziejów Cywilizacji i Kultury $V-X X$ wiek, jako X tomu Wielkiej encyklopedii geografii świata.

Uznanie światowe zyskał profesor Topolski dzięki swym rozważaniom metodologicznym. Zawdzięcza je swojemu niezwykłemu talentowi, bowiem metodologiem się jest, a nie staje się nim. Twórczość metodologiczna nie da się uprawiać bez iskry bożej. Talent poparty niezwykłą erudycją oraz pracowitością owocował wspaniale. Zwiastunem publikacji na ten temat była książka Andrzeja Malewskiego i Jerzego Topolskiego Studia z metodologii historii (Warszawa 1960). Kolejną publikacją z tego zakresu jest dzieło na skalę światową Metodologia historii (Warszawa 1968). Sięgam do niego nie bez wzruszenia. Była to pierwsza książka, którą autor ofiarował mi z dedykacją „Drogiemu Leszkowi z wyrazami przyjaźni, Jurek, VI, 68”. Dzieło to w Polsce doczekało 
się trzech wydań, zostało przetłumaczone na język angielski (USA, Holandia), włoski, hiszpański, chiński, rumuński, rosyjski i wietnamski. Celem kolejnych książek z tego zakresu było: „[... ] wprowadzenie czytelnika w nowoczesne myślenie o historii [...]”. Stworzył własną poznańską szkołę metodologii i teorii kultury.

Wspomnieliśmy o fenomenalnym talencie Profesora, był geniuszem. Jego szalona erudycja była wynikiem tytanicznej pracowitości, umiejętności koncentrowania się na najważniejszych problemach, wewnętrznego zdyscyplinowania i umiejętności organizowania warsztatu naukowego. Wykorzystywał każdą chwilę, aby pracować, Gdy wsiadał do pociągu czy samolotu natychmiast wyciągał kartki papieru, książkę i tworzył. Podczas XV Międzynarodowego Kongresu Nauk Historycznych w Bukareszcie w 1980 roku przyszło nam wysłuchiwać nie bardzo interesującego wystąpienia pani minister edukacji Rumunii. Podczas jej wystąpienia profesor Topolski coś pilnie i intensywnie notował. Gdy wróciliśmy do hotelu miłe recepcjonistki odnosiły się do nas z niezwykłą atencją i w końcu oświadczyły: „byli panowie w telewizji”. Kamerzyści byli głęboko przekonani, że profesor Topolski był jedynym, który skwapliwie coś pisał. Tymczasem profesor pisał wstęp do rumuńskiego wydania Metodologii.

Nieobca Mu była popularyzacja historii. Bez trudu przechodził do narracji bliskiej najmłodszym miłośnikom historii. Trudny lot orła białego. Rozmowy o historii (Warszawa 1996), książka, napisana w formie dyskusji z Anią i Tomkiem, dziećmi Profesora. W sumie opublikował 1100 pozycji, w tym 25 książek. Był genialny. Jego ogromna erudycja była wynikiem przysłowiowej tytanicznej pracowitości.

Jego światową pozycję jako uczonego uhonorowano licznymi prestiżowymi nagrodami i godnościami, które trudno byłoby tu wymienić. Warto wspomnieć, że pełnił też wiele ważnych funkcji, był dyrektorem Instytutu Historii UAM, kierownikiem Zakładu Historii Nowożytnej IH UAM, przewodniczącym Komitetu Nauk Historycznych PAN, członkiem międzynarodowych stowarzyszeń i organizacji, redakcji czasopism polskich i międzynarodowych.

Ożywiona była aktywność dydaktyczna, wypromował 50 doktorów, patronował wielu pracom habilitacyjnym. Wykładał na licznych uniwersytetach zagranicznych. Występował jako referent na kolejnych Międzynarodowych Kongresach Historycznych. Był poliglotą, biegle władał francuskim, niemieckim, angielskim, rosyjskim, holenderskim, swobodnie porozumiewał się też we włoskim i hiszpańskim, co czyniło $\mathrm{z}$ niego prawdziwego ambasadora nauki polskiej.

Wydawać by się mogło, że był typem badacza zamkniętego w swym gabinecie. Tymczasem Jurek był człowiekiem serdecznym, życzliwym, koleżeńskim, skromnym, dla którego słowo przyjaźń miała najgłębszy sens. Brzydził się wszelkiej przemocy 
i bolał nad losem przyjaciół i kolegów, którzy padli ofiarą Marca 1968 roku. Spieszył z pomocą potrzebującym. Gdy w 1975 roku pisał u mnie pracę magisterską Adam Michnik, Profesor Topolski podjąl się natychmiast jej recenzowania, a „czasy - jak mówił późniejszy redaktor Gazety Wyborczej - byly parszywe”. W czasie stanu wojennego, gdy studenci ostatniego roku, zaangażowani w działalność opozycyjną, wypuszczani byli na wolność i dramatycznie starali się sfinalizować studia, Profesor odkładał wszystko i dniami, i nocami czytał i recenzował prace magisterskie, aby studenci - nim zorientowały się określone służby - mogli ukończyć studia.

Nie zamykał się w kręgu badań historycznych. Interesując się literaturą, sztukami pięknymi, teatrem, muzyką, operą, uważal, że obcowanie z muzami otwiera horyzonty i pobudza intelektualnie. Przywodzi to na myśl postępowanie ludzi renesansu. Profesor Topolski znajdował czas, aby zwiedzać zabytki, muzea, galerie. Pamiętam, jak podczas XVII Międzynarodowego Kongresu Nauk Historycznych w Madrycie w 1990 roku, pomknęliśmy w naszym poznańskim gronie do Toledo, by podziwiać piękno tego miasta i wspaniałą kolekcję el Greco. Do jego przyjaciół należeli malarze, rzeźbiarze, dyrygenci, profesorowie różnych profesji, lekarze, prawnicy. Nietrudno sobie wyobrazić atmosferę panującą w willi państwa Danusi i Jurka Topolskich przy ulicy Bastionowej. Przywoływała ona na myśl salony dziewiętnastowiecznego Poznania. Na spotkaniach rozbrzmiewał wielojęzyczny gwar dyskusji o sztuce, literaturze, filmie, teatrze i całkiem błahych sprawach. Siedzieliśmy w przestronnej, stylowej piwnicy z witrażami Marii Powalisz-Bardońskej, przy przepysznie zastawionych stołach, kielichach napełnionych przednim winem. Nie brak było i śpiewów, nie zbiorowych, ale naszego dwuosobowego chóru, niekiedy zasilanego przez innych uczestników spotkania. Repertuar był całkiem bogaty, składał się z trzech części: pieśni ludowych, ze sławną pieśnią dziadów wileńskich, repertuaru międzynarodowego, tu szlagierem było wykonanie w wersji oryginalnej, niemieckiej, Mackie Majcher oraz pieśni patriotycznych, które otwierała pieśn wojskowa Wśród nocnej ciszy pod Lwowem, stoi Poznańczyk przed wrogiem.... Finałem popisu była tzw. gwiazda leżąca. Polegało to na tym, że trzymając w dłoni kielichy napełnione winem i wspierając się na drugiej ręce, w parterze, śpiewaliśmy: niech mu gwiazda pomyślności... Bawiliśmy się wybornie.

Dziedziną, którą teoretycznie nie interesował się prof. Topolski był sport, ale to nie znaczy, że go nie uprawiał. Uwielbiał pływanie. Uroki tej dyscypliny zgłębiał pod okiem naszych uniwersyteckich instruktorów. Latem plywał w Boszkowie, gdzie miał letni domek oraz w Morzu Śródziemnym, głównie na wyspie Rodos, gdzie spędzał $\mathrm{z}$ rodziną wakacje. 
Był twardy jak skała. W życiu stosował zasadę keep smiling. Absolutnie obce było mu użalanie się, skarżenie się na przeciwności losu. Podczas wizyty u Niego w szpitalu 20 XII 1998 roku, na dzień przed Jego śmiercią zastałem Go czytającego jakiś tygodnik. Profesor, jakby z usprawiedliwieniem, powiedział do mnie: „Widzisz, Leszku, nie pracuję, doszedłem wreszcie do wniosku, że muszą trochę wypocząć”. Zwrócił się do mnie z prośbą: „Leszku, nie mów nikomu, że jestem w szpitalu. Za kilka dni wyjdę, nikt nie zauważy mojej nieobecności”.

Tę ogromną, niepowetowaną stratę oddają słowa prof. Bogumiła Jewsiewickiego, profesora historii na Université de Laval w Quebecu: „Profesor Topolski był w pełni sił intelektualnych, jak najlepsze wino, z wiekiem rosły nieustannie wartości i głębia zrozumienia ludzkich postępowań zawarte w Jego pracach. Dla historyków, ale również dla wszystkich, którzy zajmują się zrozumieniem naszego świata, Jego dorobek jest bezcenny. Dla polskiej nauki był On zawsze i pozostanie na długo jednym z jej najlepszych ambasadorów, być może najlepszym w drugiej połowie tego wieku”.

Cześć Jego Pamięci. 